\title{
The Complexities of Electronic Services Implementation and Institutionalisation in the Public Sector
}

\author{
Ramzi El-Haddadeh \\ Ramzi.El-Haddadeh@brunel.ac.uk \\ Business School, Brunel University, \\ UK \\ Vishanth Weerakkody \\ Vishanth.Weerakkody@brunel.ac.uk \\ Business School, Brunel University, \\ UK \\ Shafi Al-Shafi \\ Shafi.Alshafi@yahoo.com \\ Ministry of Interior \\ Qatar
}

\begin{abstract}
Electronic service implementation (ESI) in the public sector attempts to improve efficiency, effectiveness, and transparency of governmental departments. Despite having provided the necessary infrastructure and investment, many governments have struggled to realise such aims due to the various forces that challenge implementation and institutionalisation. Using institutional theory as a lens, we explored the forces influencing the implementation and institutionalisation of ESI in the public sector. While our results reinforced previous research in IT implementation and organisational transformation, they showed that the dynamic nature of technology poses unanticipated pressures, and that these can impede the implementation and institutionalisation process.
\end{abstract}

Keywords: public sector, electronic services, IT implementation, institutional theory, organisational transformation 


\section{Introduction}

With the emergence of e-service delivery in the public sector (ESD-PS) administrations around the world have realised the importance of making their service more efficient, transparent, and available to all stakeholders [1]. They have tried to emulate the private sector by offering more citizen-centric, accessible services [24]. Different researchers have identified factors that entice governments to implement e-services. For instance, Carter et al. [4] argued that e-services can help restore public trust by coping with corruption, inefficiency, ineffectiveness and policy alienation. Conversely, lack of access them and the digital divide may influence trust and thus impede the addition of e-services.

A common argument that surfaces is that ESD-PS offers many benefits and can potentially provide opportunities to governments [11]. Yet, its implementation has faced many barriers that have contributed to delayed projects and sometimes even failures. The reasons for such barriers are often triggered by the complexity of the changes that are introduced during implementation; these are primarily due to the use of the Internet and its array of Information and Communication Technologies (ICTs) compared to prior traditional reforms [9]. Although many studies have explored these complexities, few have adopted a critical and theoretical stance to understand their impact of ESD-PS.

The State of Qatar in Western Asia was used as the empirical context for our study, as it involved a place where both high investment and strategic commitment were needed to make the radical transformations to the public sector using ESI. In this respect, our focus was intended to answer the question: what forces influence the institutionalisation of e-service delivery and its subsequent impact on reshaping the public sector organisation? Our research also used institutional theory to formulate a conceptual frame of reference to synergise e-service implementation (ESI) complexities in the PS and offer a reference point for practitioners and researchers involved in PS ESD to relate implementation paradoxes and associated complexities.

\section{Analysing E-Service Implementation Complexities in the PS: A Theoretical Lens}

PS ESI is expected to provide efficient, low cost, rapid service to customers, centralized government service to stimulate economic development, reduce corruption, improve transparency, and create a more participative form of government by encouraging online debating, voting, and exchange of information [8, 12, 13]. Thus the major issue in the development of PS e-service is to maximise the benefits and make use of any opportunity for 
improvement using ICT. The problems of implementing ESI include: lack of readiness and awareness, access to e-services, usability of public sector e-service websites, lack of trust, concerns about privacy and security, resistance to change, lack of skills and funding the digital divide, lack of citizens' interest, lack of government support, lack of legislation, and lack of strategy and frameworks. These are hindering the implementation and adoption of PS sector eservices in many countries [20]. Nevertheless, in an environment where citizens' needs and demands continuously change, institutions need to respond as quickly as possible to the changes. Thus, an institution's response to change will depend on socio-, politico-, organisational-, and technological- developments and trends in different contexts, influenced by external aspects that are more complex than the internal influences that impact more conventional organisational changes [27].

Institutional theory has been used by many scholars to explain this; it offers an appropriate conceptual lens with which to study organisational change in public sector and e-service contexts. Kim et al. [19] found that strong leadership was crucial to success. Similarly, Currie and Guah [7] explored the complexities of implementing e-systems in the National Health Service and the associated pressures influencing change. Additionally, the pressures have led public institutions to adopt online services and several features of ICT such as security, privacy and interoperability standards for building systems. These studies are further corroborated by Baptista et al. [2] who emphasised the significant role that technology can play in maintaining institutional stability While these studies offer insights into the implementation and institutionalisation of technology, only limited research effort has been expended on ESI in the public sector using an institutional lens. These isomorphic mechanisms can be categorised as coercive, normative, or mimetic, where the first two are controlled via interconnected relations while the last is controlled by structural equivalence.

For coercive pressures, public institutions often enforce regulations in order to direct the behaviour of citizens under their influence. However, they can be enforced under by their ES. Liang et al. [23] argued that there are two types of coercive pressure in PS ESI: formal (direct) or informal. Direct pressures are reports required for a specific procedure while indirect pressure arises in organisations that are associated with government. Likewise, in a PS ESI context, the government will assign a governmental unit that acts as a regulatory body to develop and implement different phases of ESI projects, while other governmental units will follow the rules and regulations assigned by this unit. Consequently, the inclusion of any additional ES will follow the same rituals and apply the same rules. This will ensure the success of governmental organisations in implementing such technologies. With regards to normative pressures, in 
bureaucratic organisations, such as PS, they influence and control the practices, rules and beliefs of those within the system of the institution. In this respect, ICT innovations can be considered part of the normative influences. Thus, if technology is implemented in an organisation, external people and organisations will consider it to be legitimate.

Modern institution theory views mimetic pressures as the result of notions, ideas, and values in meaningful systems. Thus they mould a structural equivalence among organisations that helps diffuse good business practices among organisations in the same business domain. Teo et al. [25] listed the ways that organisations mimic one another; they suggested that the same economic position, same industry, same goals and objectives, same challenges, same conditions and sharing the same customers and suppliers are key reasons for mimetic behaviour. Therefore, in the context of ESD, when the network among internal and external organisations expands, its complexity will increase, resulting in competitive advantage because of the relationships between internal subunits and external organisations. As a result, ESD affects the government agencies so that each public institution will be encouraged to adopt online services. We therefore decided to study PS ESI related change by considering the key forces influencing implementation from political, social, organisational and technology aspects.

\section{Theme 1: Political Influence}

Traditionally, institutional theory involves forming new rules, procedures, arrangements and actions that are required to develop a successful organisation. These will affect the decisions and behaviour of leaders and decision makers in the organisation. Strong government support, financial resources, political leadership, and legal and regulatory issues are essential at all levels of government in order to achieve PS transformation. Top management support and commitment is an important factor in shaping an institutions' structure; PS organisations require individuals with the right attitude and leadership ability as well as a good understanding of ESD and its impact on local, regional, and national aspects of government. From an institutional perspective, leadership has influence over and above mechanical compliance with the routine directives of the organisation. Funding facilitates the infrastructure (buildings, technologies, and human resources) that is needed to implement e-services within given targets and milestones. Consequently, organisational procedures and policies are accepted as legitimate and rational means to attain organisational goals. The new actions and arrangements that are influenced by organisational change that takes place because of PS ESI are likely to impact the decisions and behaviour of leaders and decision makers in the organisation [14]. In particular, e-services will require many regulations and legislation acts to cope with changes such as electronic signatures, 
insuring data protection, and preventing computer crime and hackers, in addition to freedom of information. These political forces that influence ESI in the PS sector are presented in table 1.

Table 1. Political forces influencing the Implementation and Institutionalisation of ES in the PS

\begin{tabular}{|l|l|l|}
\hline \multicolumn{1}{|c|}{ Forces } & \multicolumn{1}{|c|}{ Description } & \multicolumn{1}{c|}{ Institutional Theory Dimension } \\
\hline $\begin{array}{l}\text { Government } \\
\text { support }\end{array}$ & $\begin{array}{l}\text { Top management commitment and } \\
\text { support during the implementation of } \\
\text { e-services projects }\end{array}$ & $\begin{array}{l}\text { Providing support for development of new rules, } \\
\text { procedures, arrangements and actions }\end{array}$ \\
\hline $\begin{array}{l}\text { Availability of } \\
\text { Funding }\end{array}$ & $\begin{array}{l}\text { Long term financial support to } \\
\text { maintain sustainability of e-services }\end{array}$ & $\begin{array}{l}\text { Political commitment to provide the necessary } \\
\text { infrastructure and resources for maintaining the PS }\end{array}$ \\
\hline $\begin{array}{l}\text { Leadership } \\
\text { Qualities }\end{array}$ & $\begin{array}{l}\text { Ability to deliver and reach the goals } \\
\text { of various e-service projects in the on } \\
\text { time and within budget }\end{array}$ & $\begin{array}{l}\text { Behaviour of leaders and decision makers to } \\
\text { understand all impacts of PS e-services }\end{array}$ \\
\hline $\begin{array}{l}\text { Legal and } \\
\text { Regulatory } \\
\text { issues }\end{array}$ & $\begin{array}{l}\text { Regulations and legislation to ensure } \\
\text { required change due to e-services }\end{array}$ & $\begin{array}{l}\text { Providing support for regulatory and legal issues at } \\
\text { all levels of government to achieve PS } \\
\text { transformation, political power, and legitimacy }\end{array}$ \\
\hline
\end{tabular}

\section{Theme 2: Social Influence}

Public institutions that have introduced e-services have radically transformed their organisational structure using the latest technology. External pressures can control the input processes of an organisation, resulting in actions that ultimately increase the quality of services and improve customer satisfaction, by which organisations are able to reduce negative external pressure due to social behaviour in the PS ESD context. Social change should focus on providing e-services that addresses citizens' needs and deliver services that provide added value. Moreover, the general population is often unaware of e-services, and this can prevent them from participating and adopting them [3]. Further, research has shown that education and training for both citizens and government employees is an important antecedent to bridging gaps in the digital divide, these social forces are summarised in table 2.

Table 2. Social forces for influencing the Implementation and Institutionalisation of ES in the PS

\begin{tabular}{|c|l|l|}
\hline Forces & \multicolumn{1}{|c|}{ Description } & \multicolumn{1}{c|}{ Institutional Theory Dimension } \\
\hline $\begin{array}{c}\text { Citizen Centric } \\
\text { Focus }\end{array}$ & $\begin{array}{l}\text { Need to deliver services that add } \\
\text { value to citizens }\end{array}$ & $\begin{array}{l}\text { Acknowledge external pressures and take actions } \\
\text { that increase the quality of services and improve } \\
\text { customer satisfaction }\end{array}$ \\
\hline Awareness & $\begin{array}{l}\text { Promote public sector e-services to } \\
\text { improve citizens'participation }\end{array}$ & $\begin{array}{l}\text { Shaping social behaviours through an internal } \\
\text { mechanism and structure that supports and helps to } \\
\text { raise awareness of the wide spectrum of public } \\
\text { sector electronic services among citizens }\end{array}$ \\
\hline Digital divide & $\begin{array}{l}\text { Teach use and accessibility, } \\
\text { transaction services, social inclusion } \\
\text { and participation }\end{array}$ & $\begin{array}{l}\text { Use the institutional environment system to increase } \\
\text { adoption by diverse demographics }\end{array}$ \\
\hline $\begin{array}{c}\text { Continuous } \\
\text { Professional } \\
\text { Development }\end{array}$ & $\begin{array}{l}\text { Understand new work environment } \\
\text { and activities }\end{array}$ & $\begin{array}{l}\text { Organisational members learn and adapt new work } \\
\text { practices and/or services }\end{array}$ \\
\hline
\end{tabular}

\section{Theme 3: Organisational Influence}


The institutional approach has led to significant insights of the importance of institutional environments to the organisational structure and its actions. This perspective considers institutions as the modification of activities by organisational members; the transformations that take place in government institutions and the resulting improvement to their services play an important role in PS ESI. Moreover, the rapid development of the internet and supporting ICTs have increased the level of citizen/customer interaction with businesses and promoted a better develop awareness of organisations that are involved in a particular business/service domain [21]. This will lead the organisation to deal with a wide range of users with multiple languages and cultures and reduce any organisational barriers; overall, this will help to form an organisational structure that will perform better and deliver services that are more customer/citizen oriented. Doherty and King [10] argued that the implementation of new ICT to PS will result in a shifting of power in the institution's hierarchy. This is further compounded when PS institutions must prioritise resources and deliverables for various e-services projects. A comprehensive e-services strategy is essential to manage alignment, implementation, and exploitation of ICTs within PS institutions to ensure sustainability in the long term. Thus organisational culture and structure are likely to be affected. Hence, governments must adopt new strategies for e-service initiation. This discussion is summarised in table 3.

Table 3. Organisational forces influencing the Implementation and Institutionalisation of ES in the PS

\begin{tabular}{|l|l|l|}
\hline \multicolumn{1}{|c|}{ Forces } & \multicolumn{1}{|c|}{ Description } & \multicolumn{1}{c|}{ Institutional Theory Dimension } \\
\hline $\begin{array}{l}\text { Public agency } \\
\text { structure }\end{array}$ & $\begin{array}{l}\text { Work ades, administrative } \\
\text { mechanisms and associated work } \\
\text { activities }\end{array}$ & $\begin{array}{l}\text { Importance of institutional environments to the } \\
\text { agency's organisational structure and actions }\end{array}$ \\
\hline $\begin{array}{l}\text { Power } \\
\text { distribution }\end{array}$ & $\begin{array}{l}\text { Employee resistance and control over } \\
\text { business processes }\end{array}$ & $\begin{array}{l}\text { Effect of persistent changes to activities via social } \\
\text { constructions among agency employees }\end{array}$ \\
\hline $\begin{array}{l}\text { Strategic IT } \\
\text { alignment and }\end{array}$ & $\begin{array}{l}\text { Strategy alignment } \\
\text { interoperability issues between } \\
\text { systems }\end{array}$ & $\begin{array}{l}\text { Coherence between organisational and IS strategies } \\
\text { to maintain alignment }\end{array}$ \\
\hline $\begin{array}{l}\text { Prioritisation of } \\
\text { deliverables }\end{array}$ & $\begin{array}{l}\text { Delivery of strategic services } \\
\text { appropriately and on time }\end{array}$ & $\begin{array}{l}\text { Influence of forces on the changes of organisational } \\
\text { activities }\end{array}$ \\
\hline $\begin{array}{l}\text { Future needs of } \\
\text { the public } \\
\text { agency adoption }\end{array}$ & $\begin{array}{l}\text { Appropriate and } \\
\text { implementation models that address } \\
\text { future needs }\end{array}$ & $\begin{array}{l}\text { Public agency service transformations implemented } \\
\text { to replace traditional services due to pressures that } \\
\text { originated in the environment }\end{array}$ \\
\hline $\begin{array}{l}\text { Organisational } \\
\text { culture socio-cultural }\end{array}$ & $\begin{array}{l}\text { Understanding } \\
\text { differences between public agencies } \\
\text { and individuals }\end{array}$ & $\begin{array}{l}\text { Influence of the organisation's norms, values and } \\
\text { beliefs that help in establishing and integrating new } \\
\text { forms of policies and procedures in public agencies }\end{array}$ \\
\hline
\end{tabular}

\section{Theme 4: Technology Influence}

In order to gain a high level of efficiency in the PS more complex business processes will need to be implemented; they require a high level of integration between the internal and external processes and IS/IT systems of different stakeholders. Adoption of a new technology can often be explained as environmental influences that occur due to the relationships of the organisation 
(e.g. with suppliers, citizens, and employees); these and their norms will also form the basis for diffusion of new IS/IT guidelines and standards among public sector agencies. These will help local government agencies to be consistent in their ESD, while at the same time maintaining stability of the organisations IS/IT security. From an individual perspective however, employees often adopt institutional structures to make sense of technology. The influence of the discussed technological forces are summarised in table 4.

Table 4. Technology forces influencing the Implementation and Institutionalisation of ES in the PS

\begin{tabular}{|l|l|l|}
\hline \multicolumn{1}{|c|}{ Forces } & \multicolumn{1}{|c|}{ Description } & \multicolumn{1}{c|}{ Institutional Theory Dimension } \\
\hline ICT standards & $\begin{array}{l}\text { Acquirement, management and } \\
\text { utilisation of ICT assets }\end{array}$ & $\begin{array}{l}\text { Rules and standards governing the development and } \\
\text { use of ICT in public agencies }\end{array}$ \\
\hline $\begin{array}{l}\text { Security and } \\
\text { privacy }\end{array}$ & $\begin{array}{l}\text { Confidentiality, integrity, and } \\
\text { authenticity of public agency data }\end{array}$ & $\begin{array}{l}\text { Stability of the institutional perspective in IS/IT } \\
\text { security in the agencies }\end{array}$ \\
\hline $\begin{array}{l}\text { System } \\
\text { integration }\end{array}$ & $\begin{array}{l}\text { Integration across different } \\
\text { roles/departments for an optimised } \\
\text { seamless solution }\end{array}$ & $\begin{array}{l}\text { Coherence between external sources (other public } \\
\text { agencies, citizens and businesses) and employees to } \\
\text { maintain information flow }\end{array}$ \\
\hline $\begin{array}{l}\text { Accessibility of } \\
\text { E-services }\end{array}$ & Service availability & $\begin{array}{l}\text { Stability of the institutional perspective in IS/IT to } \\
\text { maintain a continuous online presence of the agency's } \\
\text { services }\end{array}$ \\
\hline
\end{tabular}

\section{Methodological Approach}

This study did not presume a straight and clear pathway of e-service change, since the implementation of ES was tied to existing bureaucratic PS traditional work practices. To achieve this objective, our study followed the historical evolution of ES implementation and institutionalisation complexities in Qatar's PS over an eleven-year period (2000 until 2011) aiming to capture all complex changes to the ES. The longitudinal approach adopted offered the needed depth to study the Implementation and Institutionalisation of e-services in the public sector over time. The only sources of published information on ESI in the State of Qatar are official government reports and publications. However, these publications neither provided an overall picture of the current situation nor highlight the benefits and current complexities facing ESI in sufficient depth. Therefore, the appropriate way to explore the various factors influencing ESI in Qatar was through empirical research in conjunction with available secondary resources. We therefore adopted a qualitative single, exploratory longitudinal, in-depth case study approach by using semi-structured interviews. Such approaches were deemed necessary to realise the aim of our paper.

The data collection process covered an analysis of documents over the period 2000-2011 and three sets of interviews with key stakeholders over a period of three years (between 2007 and 2009). Eight officials who were directly involved in and responsible for ESI were interviewed at the Ministry of the Interior (MOI): the e-services Director, Director of Telecommunications, two 
Senior Infrastructure Engineers, one Senior Application Engineer, and two Middle Managers who were responsible for e-services projects and one Software Engineer. Crouch and Mckenzi [5] had posited that selecting a manageable number of participants can help in building a close association between the researchers and interviewees, resulting in an accurate and naturalistic setting for the empirical enquiry. All of the interviewees had official government approval to participate in our study. The MOI was selected as most of the e-services that are offered in the State of Qatar are developed, implemented and provisioned by this ministry. All interviews were tape recorded with permission and subsequently the interviewees were given the transcripts to check and resolve any discrepancies or to eliminate any bias. Semi-structured interviews were used to maintain focus on the relevant issues, and lasted about two hours. Follow up informal interviews were conducted in August 2011 and February 2012 to further explore and triangulate the findings with secondary document reviews to reflect the longitudinal evolution of ES implementation and institutionalisation.

As suggested by Currie [6] multiple levels of analysis were used in the empirical inquiry to reflect the normative context, including political, social, organisational and technology contexts, and the individual participant's professional background, knowledge and role in Qatari PS ESI. A total of 41 documents were collected, indexed and analysed. These covered a wide range of information including; new policies, management and internal reports, and white papers from MOI and ictQatar (established in 2004 to oversee ESI in Qatar) over a 10 years period. These documents offered insights on the institutions' history and past project experiences, and allowed triangulation and validation of the findings. The data analysis process was done manually and began by examining the verified transcripts for emerging themes against the conceptual frame of reference. Finally, the themes, along with the associated forces, were mapped to maintain further verification through cross checking against the individual empirical source [22].

\section{Findings and Analysis}

The State of Qatar is a peninsula with a strategic position at the centre of the west coast of the Arabian Gulf with an estimated population of around 1.5 million, of which the majority are expatriate workers. In global terms, Qatar's ESD initiative was ranked at 48 in 2012, this is an improvement from 2010, when it was ranked at 62 [26]. The evolution of formal ESD in Qatar spans a little more than a decade and was initially limited to shared activities among government agencies (a Network of National Information). The ESD activities in Qatar were initially managed independently by government ministries and went through a series of development phases before ictQatar assumed overall responsibilities as outlined in table 5 . 
Table 5. Summary of ESD evolution in Qatar

\begin{tabular}{|c|c|c|}
\hline \multicolumn{2}{|c|}{ Year } & ESD PS Evolution \\
\hline \multicolumn{2}{|c|}{1990 ’s-2000 } & $\begin{array}{l}\text { limited number of national IT projects (Network of National Information), and other } \\
\text { government-to-government activities. These were often managed independently and } \\
\text { provided static information. Some advanced facilities were provided. }\end{array}$ \\
\hline \multirow{3}{*}{ 2000-2004 } & Phase 1 & $\begin{array}{l}\text { The Qatari government launched its national ES project in July with a pilot project } \\
\text { as the first phase to renew residential permits. This was an initiative of the } \\
\text { Department of Immigration and Passports - Ministry of Interior (MOI). This service } \\
\text { was chosen as a pilot phase with two months from conception to completion. }\end{array}$ \\
\hline & Phase 2 & $\begin{array}{l}\text { Because of the success of the pilot project, the government of Qatar supported the } \\
\text { start the second phase by collaborating with an international consulting company to } \\
\text { draw upon international best practices in the two-year period to } 2002 \text {. }\end{array}$ \\
\hline & Phase 3 & $\begin{array}{l}\text { Represented the implementation of grouped services as part of ESD. The vision of } \\
\text { this phase was "Qatar online services, anytime, anywhere, providing government } \\
\text { transactions information and knowledge" }\end{array}$ \\
\hline \multicolumn{2}{|c|}{2005} & $\begin{array}{l}\text { The ictQATAR Supreme Council, established in 2004, took over the national ES } \\
\text { initiative with a responsibility to manage and develop the overall ICT strategy in } \\
\text { Qatar (infrastructure service delivery and legal aspects of public services). } \\
\text { ictQATAR took overall control of the national ES initiative with a plan for e-health } \\
\text { and e-education programs using a phased implementation. }\end{array}$ \\
\hline \multicolumn{2}{|c|}{ 2006-2007 } & $\begin{array}{l}\text { ictQATAR set its target to maintain the development of its ESD through setting up } \\
\text { the infrastructure and associated standards and updating the associated legal and } \\
\text { regulatory policies. Secured portal and business services were integrated within a } \\
\text { data centre to facilitate the management of ESD. In addition, central government } \\
\text { started to build its network across its agencies as well as setting up a payment } \\
\text { platform. Finally, pertinent ICT and computer application training and various } \\
\text { marketing and awareness campaigns were adopted to promote the benefits of ES. }\end{array}$ \\
\hline \multicolumn{2}{|c|}{ 2008-onwards } & $\begin{array}{l}\text { Moving towards business intelligent oriented ESD and by optimising the required } \\
\text { organisational performance management tools, further intra-organisational and } \\
\text { citizen centric services were introduced. Also these ES were targeted towards } \\
\text { increasing citizens' participation by developing new engagement platforms, such as } \\
\text { self-service terminals (kiosks), and relevant mobile technologies. }\end{array}$ \\
\hline
\end{tabular}

It is evident that ESI went through an institutionalisation process between 2000 and the present; this conforms to the values that underpin institutional theory. ESD has become part of the normal service delivery process in the public sector and the associated policies controlling engagement with stakeholders. At the same time, the implementation of ES has resulted in organisational changes that have enforced formal procedures and organisational routines. Furthermore, it is evident that the institutionalisation of ESD has been influenced by political, social, organisational and technological forces that have contributed to shaping ESI through its inception to the present. As summarised in table 6, many of these forces are consistent with institutional theory. However, a number of unanticipated forces were identified in our empirical study that had not previously been examined. These included, a) building a collaborative environment among public agencies, b) recognising partnerships as the way to move to sustainable ESD, c) investing in local resources to maintain the stability and sustainability of ESD, and d) maintaining the capacity of policy makers to respond to external pressures. 
Table 6. Forces influencing the Implementation and Institutionalisation of ES in the Qatari PS

\begin{tabular}{|c|c|}
\hline Forces & Empirical Evidence from the Case Study \\
\hline \multicolumn{2}{|r|}{ Organisational Theme } \\
\hline $\begin{array}{l}\text { Public Agency } \\
\text { Structure }\end{array}$ & $\begin{array}{l}\text { The MOI faced rapid development and changes due to ESI resulting in a major restructuring } \\
\text { of its organisation. This has also required some change in policies, procedures, and business } \\
\text { process ownership. ESI has caused the MOI to streamline its business processes and } \\
\text { services. As well as its dealings with other government agencies and ministries. Traditional } \\
\text { administrative norms built on vertical hierarchies and seniority has shifted to horizontal } \\
\text { structures focused on team work and collective decision making. }\end{array}$ \\
\hline Power Distribution & $\begin{array}{l}\text { ESI has encountered some resistance due to change in organisational structure and } \\
\text { hierarchy. However, due to the lack of expertise, there has been dependency on other } \\
\text { government agencies' technical expertise to help develop e-services. Such contexts have } \\
\text { changed the social setting in public organisations where established social norms were } \\
\text { challenged by a focus on professionalism and obtaining results. }\end{array}$ \\
\hline $\begin{array}{l}\text { Prioritisation of } \\
\text { Deliverables }\end{array}$ & $\begin{array}{l}\text { The Qatari ESD master plan identified } 52 \text { services grouped according to four stages of } \\
\text { implementation. Each had a number of initiatives, including a clear timeline for each } \\
\text { initiative and its associated services. Furthermore, the placement of these initiatives and } \\
\text { services under each stage was driven by a set of priorities that were defined by the } \\
\text { government. These priorities were influenced largely by internal forces emanating from the } \\
\text { Qatari government, which showed a desire and commitment to be the first users of ESD in } \\
\text { the region. }\end{array}$ \\
\hline $\begin{array}{l}\text { Future Needs of the } \\
\text { Public Agency }\end{array}$ & $\begin{array}{l}\text { As a key priority, ictQatar created the environment and infrastructure for e-services } \\
\text { development; thus has contributed considerably towards the country's implementation of its } \\
\text { ES. Moreover, further developments have been identified and prioritised to encourage the } \\
\text { adoption of e-services. In particular, multi-channel ESD using kiosks and ubiquitous } \\
\text { technologies have been implemented as part of the strategy. Interestingly, the } \\
\text { implementation of such innovative ESD facilities does not point at coercive, normative, or } \\
\text { mimetic behaviour, but was seen to be setting the direction for future behaviour. }\end{array}$ \\
\hline $\begin{array}{l}\text { Organisational } \\
\text { Culture }\end{array}$ & $\begin{array}{l}\text { ESI has resulted in changes to establish work procedures and routines as well as the vision, } \\
\text { values and norms, resulting in a major shift in how employees and external stakeholders } \\
\text { perceive MOI. Since 2005, such a shift helped MOI together with ictQatar to propose and } \\
\text { rapidly establish and integrate new policies and procedures for ESD. Thus interviewees } \\
\text { concurred that the introduction of ES to the PS has had a profound impact on the } \\
\text { organisational culture of Qatar where established norms and beliefs have been } \\
\text { fundamentally challenged and thus forcing senior managers to change their behaviour. }\end{array}$ \\
\hline $\begin{array}{l}\text { Strategic Alignment } \\
\text { of ESI/ESD }\end{array}$ & $\begin{array}{l}\text { The ESI strategy was aligned with other initiatives showing that it falls under one ICT } \\
\text { strategy and the responsibility of ictQatar under the supervision of MOI. The ESI team } \\
\text { consists of business and IT professionals who share and discuss the alignment between IT } \\
\text { and business strategy across government agencies. Interviewees agreed that such notions of } \\
\text { business-IT alignment were rarely seen as important prior to } 2001 \text {. As a result, towards } 2005 \\
\text { the government appointed a single owner for each of the } 52 \text { service areas identified in their } \\
\text { master plan; this owner has been responsible for overseeing the alignment of ESI with the } \\
\text { associated ministries' business plans. Thus, the policies and procedures for ESI have } \\
\text { pressured other ministries. It was clear that the national strategy for ESI was set by the } \\
\text { central government. Although MOI and ictQatar were able to influence this strategy, there } \\
\text { was very limited scope for negotiation and trade-offs between central government and local } \\
\text { ministries. Thus the Qatari ESI strategy was delivered using a 'top-down' approach. }\end{array}$ \\
\hline \multicolumn{2}{|r|}{ Political Theme } \\
\hline $\begin{array}{l}\text { Government Support } \\
\text { for ESI/ESD }\end{array}$ & $\begin{array}{l}\text { News media, government reports and a number of initiatives (such as Internet Parks and } \\
\text { ESD Kiosks) that have been launched in recent years confirm that there is strong } \\
\text { government support and commitment for ESD in Qatar. This was verified during interviews. } \\
\text { For example, support for establishing new policies and legislation towards services that are } \\
\text { associated with law and order, such as traffic violations, have been rapid compared to ESI's } \\
\text { associated with city administration. }\end{array}$ \\
\hline Funding for & Although it was clear that the government has put in place all necessary funds to ensure \\
\hline
\end{tabular}




\begin{tabular}{|c|c|}
\hline ESI/ESD & $\begin{array}{l}\text { successful ESI, the key challenge appeared to be in maintaining and releasing these funds } \\
\text { when needed. Senior managers were of the opinion that adequate financial resources were } \\
\text { made available by the government, however, there was some concern that processing the } \\
\text { required funds for different ESIs often required going through bureaucratic approval } \\
\text { procedures resulting in considerable delays. Based on the empirical findings, over } \$ 400 \\
\text { million estimated budget has been made available for ESI and development in Qatar. This is } \\
\text { a considerable sum given the size and population of the nation. }\end{array}$ \\
\hline $\begin{array}{l}\text { Leadership to } \\
\text { Champion ESI/ESD }\end{array}$ & $\begin{array}{l}\text { The interviewees thought that those responsible for ESI were coerced by external pressures } \\
\text { from the government to demonstrate the required leadership qualities for ensuring the } \\
\text { success of ESI. Since the establishment of ictQatar in 2005, the expectations from senior } \\
\text { management have increased. Also there was some confusion among employees about the } \\
\text { motivation of their leaders to champion the cause of ESI and ensure its successful } \\
\text { implementation and sustainability. For instance, there was some perception that senior } \\
\text { managers were simply following orders to implement ESI and were not fully committed to } \\
\text { delivering its benefits to the community. }\end{array}$ \\
\hline $\begin{array}{l}\text { Legislation and } \\
\text { Regulatory Issues }\end{array}$ & $\begin{array}{l}\text { The government has established a new initiative under the ESD umbrella by developing the } \\
\text { e-transaction law (cyber law) in Qatar. This initiative was drafted under the approval of the } \\
\text { cabinet in } 2005 \text { and provided the legal support framework for ESD. Although initially the e- } \\
\text { transaction laws were seen as impeding innovation in ESI, many public sector organisations } \\
\text { began to share the perception that legislation is an influential factor prior to and during the } \\
\text { implementation of a large-scale IT project in government. }\end{array}$ \\
\hline \multicolumn{2}{|r|}{ Social Theme } \\
\hline $\begin{array}{l}\text { Citizen Centric } \\
\text { Focus }\end{array}$ & $\begin{array}{l}\text { The empirical findings show that in } 2008 \text {, the government initiated a training programme } \\
\text { that was focused on teaching citizens how to use ES by providing customised International } \\
\text { Computer Driving Licence (ICDL) training for all citizens. While prior to } 2010 \text { the majority } \\
\text { of ES were directed towards businesses, recently the government has extended its ES by } \\
\text { targeting citizens and residents through its national portal (Hukoomi) in line with well- } \\
\text { established ESD efforts in other leading countries. Such a move shows that the government } \\
\text { has been influenced by external pressure to increase the quality of services provided to all } \\
\text { stakeholders in ESD and improve customer satisfaction }\end{array}$ \\
\hline Awareness of ESD & $\begin{array}{l}\text { Interviews and official reports confirmed that awareness campaigns are part of the national } \\
\text { strategy to promote ESD. However, the advertising campaigns and promotional material } \\
\text { indicate that such campaigns were still primarily targeted towards businesses rather than } \\
\text { citizens. Conversely, those interviewed suggested that there is a need to shape social } \\
\text { behaviours through helping to raise awareness of the wide spectrum of benefits and } \\
\text { opportunities offered by ESD. }\end{array}$ \\
\hline Digital Divide & $\begin{array}{l}\text { While the early stages of ESD in Qatar was primarily focused on facilitating transactions } \\
\text { and information needs of businesses, since the appointment of ictQatar to oversee ESD, the } \\
\text { government has taken a number of steps to entice citizens to use ESD. Exemplary initiatives } \\
\text { include the introduction of Internet Parks to offer free wireless access in public places. Thus } \\
\text { ictQatar has played a key role in shifting the focus of ESI from that of business centric } \\
\text { towards citizen centricity by ensuring that appropriate strategies and measures are in place to } \\
\text { overcome potential adoption and diffusion problems related to the digital divide. }\end{array}$ \\
\hline $\begin{array}{l}\text { Continuous } \\
\text { Professional } \\
\text { Development }\end{array}$ & $\begin{array}{l}\text { During the early stages of ESI, training and professional development was seen as a 'one } \\
\text { off' activity that complemented the changes introduced through the implementation of ICT. } \\
\text { However, by 2005, continuous professional development (CPD) was considered as part of } \\
\text { the government strategy to ensure the development of technical skills, and increase } \\
\text { knowledge and professional performance standards within public sector organisations. By } \\
\text { doing this, the government has encouraged a culture of professionalism and organisational } \\
\text { citizenship among its PS workers that adds value to the way services are delivered to } \\
\text { citizens. }\end{array}$ \\
\hline \multicolumn{2}{|r|}{ Technological Theme } \\
\hline ICT Standards & $\begin{array}{l}\text { From 2005, MOI together with ictQatar have adopted an ICT reference model (ICT } \\
\text { architecture standards) to guide the government in its ESI process. All ministries } \\
\text { implementing ES were required to adhere to this reference model to ensure that ICT } \\
\text { standards are maintained appropriately throughout their ESI process. Nevertheless, } \\
\text { government officials acknowledged that there are some challenges in adopting standards for } \\
\text { software development, such as the use of the latest versions of JAVA while an old version is }\end{array}$ \\
\hline
\end{tabular}




\begin{tabular}{|l|l|}
\hline & still in use. \\
\hline $\begin{array}{l}\text { Security and Privacy } \\
\text { in ESD }\end{array}$ & $\begin{array}{l}\text { Government officials responsible for ESI indicated that since 2005 MOI introduced two } \\
\text { levels of security protocols. These are primarily focused on ensuring the protection and } \\
\text { stability of institutional processes and IS/IT systems in ESD through authentication } \\
\text { techniques. The first is implemented by using unique IDs and passwords for basic services } \\
\text { such as traffic and employment sponsorship services. The second level relates to the use of a } \\
\text { combination of smart cards, PKI, and passwords to facilitate access to confidential } \\
\text { information used in integrated services that require multiple transactions. }\end{array}$ \\
\hline System Integration to & $\begin{array}{l}\text { Since the establishment of ictQatar the efforts to establish a one stop portal for ES has been } \\
\text { accelerated, resulting in the creation and establishment of the Hukoomi website. This has } \\
\text { been achieved through a long process of integrating existing legacy systems with new } \\
\text { applications that have been introduced to enable ESD over a five year period. However, as } \\
\text { this process was significantly influenced by the need to utilise the newest ICT solutions, a } \\
\text { number of challenges have arisen, affecting the optimisation of existing middleware to } \\
\text { integrate disparate systems needed for ESI. Although attempts were made to integrate } \\
\text { disparate systems across government agencies to facilitate conjoined services through the } \\
\text { Hukoomi portal, the lack of harmonisation between external and internal) sources have } \\
\text { prevented the realisation of this goal. }\end{array}$ \\
\hline $\begin{array}{l}\text { Accessibility of E- } \\
\text { shile large investments and resources have been allocated to support ESI and continuous } \\
\text { efforts are in place to enhance the ES, Qatar has still faced a number of problems that have } \\
\text { affected the accessibility of its key e-services. For instance, the main payment gateway was } \\
\text { affected with errors for over a month in late 2008, resulting in citizens not being able to } \\
\text { complete electronic transactions. Since all electronic transactions are processed through a } \\
\text { one payment gateway, its stability depends on the institutional process and ICT capabilities } \\
\text { of the MOI to facilitate and maintain its continuous online presence. }\end{array}$ \\
\hline
\end{tabular}

In addition to the above-identified forces, a number of issues emerged. These issues include:

\section{a) E-services help in building a collaborative environment among public agencies}

Our case study indicated consensus among those directly involved in ESI that there was an initial lack of technical and project management expertise in Qatar. Although this resulted in the use of external consultants, senior MOI officials concluded that external consultants showed a lack of interest in ensuring interoperability between the complex back end IS required to facilitate ESD, and were instead pushing for proprietary solutions that required a major paradigm shift in organisational processes and technical infrastructure. As a result, MOI and ictQatar took the initiative to develop and implement an ES that would improve the existing technical infrastructure and legacy systems to fit the Qatari national context. The e-services director highlighted that "the challenge we faced in the past was around not having a forum where we collaborate and discuss with a wide range of IT experts and share knowledge, ideas, and concepts about ESI. However, since the establishment of ictQatar, this challenge has been overcome where a close collaborative relationship between MOI and ictQatar has been established enabling key stakeholders in ESI to come together and share effort and expertise”. As a result, a number of centralised services (such as government procurement, HR, finance and customs operations) have started to cooperate in ESI. 
b) Recognising partnerships as the way to move forward towards the sustainability of e-services delivery

ESI has contributed by building a collaborative environment among public agencies. However, public agencies have recently started to use existing local expertise to support their ESI efforts. MOI established a working relationship with the major local private telecom service provider in Qatar to provide e-services through public kiosks and free internet access in public parks. Also, central government has been coercing local companies involved in ESI and international consultants to collaborate by establishing formal partnerships to demonstrate long term commitment towards ensuring ESD sustainability in Qatar. The telecommunication director at MOI stated that "the government in Qatar has estimated around $\$ 400$ million as a budget for the ESI project, and the efforts need to be maximised to ensure value-added for the end-user as well as maintaining the economic sustainability to the country". A regulatory environment has been established allowing the formation of partnerships between private and public organisations.

c) Investing in local resources to maintain the stability and sustainability of e-service delivery To minimise the dependency on international consultancies and vendors, the Qatari government established a new local IT company (Maalomatiih) in 2008; it is owned by the government. This company is run by the ictQatar team and the government hopes to ensure stability and sustainability of ESD by having local industry partners to spearhead the efforts. Key stakeholders in ESI considered that this company has to provide capabilities and expertise related to ESD, e-learning, and e-Health. Furthermore, the e-services director stated that "finding the required expertise and skills in a rapidly changing environment has been a challenging task, especially at the local level. As a result, we have established a number of mechanisms in place to achieve this objective, including setting up a local IT company ... to recruit and foster the needed experts". The government has followed four steps to ensure the stability and sustainability of local human capital, a) setting up a centre of excellence for continuous professional development to evaluate skill gaps and requirements in the country, b) forming a committee to identify and acquire relevant international IT companies in Eastern Europe, India, China, and the regional market, c) building partnerships with strategic international IT companies, d) continuous recruitment of ES experts.

\section{d) Maintaining the capacity of policy makers to respond to external pressures}

There was a consensus among all interviewees that responding to change is a challenge for the government. The e-services director said: "there has been rapid development 
and considerable change in the government hierarchy over the last five years and the Qatari government has been going through a restructuring process, including its governance, ever since the introduction of ES". This restructuring also implied changes in policies, procedures, and business process ownership, resulting in organisational activities being streamlined. As a result, services are now owned by different departments and ministries, and policy makers and other government officials play a significant role in facilitating the collaborative environment across all government agencies. The e-services director claimed that "it was very important to align our priorities to the government's vision for ESI. Therefore, we have been obliged to realign our individual priorities on more than one occasion due to the changes and developments that are happening in the country". Changes in the policy makers' attitude towards external pressures have been largely influenced by an environment of professionalism and a business-like approach brought about by ESI.

\section{Discussion and Research Synthesis}

Since the emergence of ESD-PS, although many studies have explored the influence of ICT implementation, the complexities that impact ESI have been paid little attention. In particular, studies that explored the influence of political, social, organisational, and technological forces on the institutionalisation of ESI have been scarce. Although institutional theory has been applied to study ESI in the public sector [17], we argue that these studies have only applied the theory at a superficial level.

\subsection{Political Theme}

Although political support was seen to be a major force in supporting ESI, it was evident from our empirical study that, at a local (ministry) level, although adequate funding and regulatory mechanisms were put in place, there was a lack of clear understanding of how ES will be adopted within the organisation. Consequently, how to facilitate improvements and contribute to the organisation's long term strategic vision was unclear. The continuous change of government priorities, compounded by bureaucratic hierarchies, resulted in ambiguity and lack of direction that made it difficult for senior managers to demonstrate their leadership to ensure the success of ESI. Given the huge expectations placed by the Qatari government for ESD to succeed, we posited that if ESD failed to be institutionalised as a new way to deliver public services, it would have a major impact on the national agenda for ESD. In fact, the continuous change of priorities for ESI has been influenced by the focus on short-term gains, whereas the institutionalisation of 
technology is a gradual process. Such a context is contrary to Jaeger and Thomson's [15] and Ke and Wei's [18] studies that highlight the significant role that senior management play in guiding the long-term direction, priorities, and resources in ESI projects.

\subsection{Social Theme}

External pressures can control the input processes of an organisation, resulting in actions that should ultimately increase the quality of services and improve customer satisfaction. While initial ESD efforts were directed towards businesses, recent ESI efforts have been targeted towards citizens and residents who are influenced by external forces in leading countries. In particular, it was clear that the Qatari government has the aspiration to become a leader in innovation and technology in the region, and ESI was thus seen and influenced partly by social values and norms derived from these aspirations. However, the empirical evidence suggests that there was a general lack of awareness of the wide spectrum of benefits and opportunities offered through ESD. In a diverse demographic setting, there was therefore a need to raise awareness through ICT education and training, and continuous professional development, to bridge the digital divide across society in order to shape social behaviours to the use of ESD. We noticed that ESI in the PS in Qatar was more focused towards businesses with limited attention to citizens' needs.

\subsection{Organisational Theme}

The impact of organisational factors in PS ESI initiatives was influenced by the prevailing organisation and management structure in Qatar. The rapid developments and changes in priorities of ESI have resulted in the MOI radically restructuring its organisational hierarchies, administrative norms, policies and business process ownership status. It was evident that ESI was encouraging inter organisational collaboration, which had been rare in the past, resulting in established social norms being challenged by a focus on team working, knowledge sharing and professionalism. Interviewees concurred that ESI has had a profound impact on the organisation culture in MOI where established norms and beliefs have been fundamentally challenged, forcing senior managers to change their behaviour. However, our case study also revealed that project leaders were frequently hindered due to the rigid organisational structure and lack of flexibility in the national ESI strategy. Also, it was evident that changes to public institutions caused a redistribution of power of individuals, resulting in some ambiguity in roles and resistance to change. As a result, the implementation of some services was delayed or moved to a lesser priority status. 


\subsection{Technological Theme}

The lack of alignment of the PS ESI plan with the overall ICT strategy in Qatar emerged as a key factor that delayed the progress of ESD. IS/IT was seen as a mechanism to improve efficiency of business processes by enacting structural and behavioural changes within the organisation. One of the key issues revolved around the appropriate use of ICT standards and associated integration issues faced by public agencies. Janssen and Cresswell [16] identified IT standards as a major factor during the implementation and integration of various technologies in a public sector e-services context. All ministries implementing ES are required to adhere to a reference model for ESI provided by MOI and ictQatar, to ensure the maintenance of standards throughout the ESI process. But, the application of standards was seen as a problem as ESI involved integrating new ICTs with existing legacy systems. This integration dimension was seen as a key success factor to enable access to PS e-services through a single portal.

\section{Conclusion}

Public sector e-services are primarily enabled by the Internet and associated ICTs that continuously evolve. In addition, PS ESI initiatives have faced numerous barriers resulting in delays, unsatisfactory outcomes and failures. We have attempted to highlight some of the key complexities that can impede PS ESI. Clearly, there is a lack of prior published research that has explored implementation aspects, and the complexities of PS e-services from a theoretical angle. Hence, we aimed to gain a better understanding of the complexities influencing implementation and institutionalisation empirically.

Our study offered a number of insights to policy makers and practitioners on the implementation and institutionalisation of ES in the PS. It highlighted the changing dynamics that ESI poses as a challenge to PS organisations in maintaining political will and commitment as well as ensuring the necessary infrastructure and resources throughout ESI projects. These dynamics force central governments to change their national priorities for ESD resulting in local government agencies/ministries having to respond promptly to make changes. In this respect, PS organisations will need to exploit local resources, while at the same time maintaining flexibility to establish collaborative partnerships when needed, in order to ensure the stability and sustainability of ES implementation and institutionalisation.

The aim of our paper was to examine the complexities of PS ESI and associated forces influencing institutionalisation. The strong strategic commitment, availability of infrastructure and financial resources made the State of Qatar a relevant and meaningful environment for a 
qualitative case study. While we acknowledge that the results of this study should be interpreted with this empirical context in mind, we argue that since the focus of this paper is on examining the PS ESI and associated forces influencing institutionalisation, the findings offer valuable insights to policy makers, practitioners and the community at large. In addition, it has to be noted that out research only focused on the complexities facing PS ESI and did not investigate how these may influence citizens' adoption of ES. The authors hope that this research has exposed a number of key forces that highlight the paradoxical nature of e-service implementation and institutionalisation in the Public Sector.

\section{References}

1. J. F. Affisco, K. S. Soliman, E-government: a strategic operations management framework for service delivery. Business Process Management Journal, 12 (1), 2006, pp. 13-21.

2. J. Baptista, S. Newell, W. L. Currie, Paradoxical effects of institutionalisation on the strategic awareness of technology in organisations, Journal of Strategic Information Systems, 19(3), 2010, pp. 171-183.

3. L. Carter, V. Weerakkody, E-Government Adoption: A Cultural Comparison, Information Systems Frontiers, 10(4), 2008, pp. 473-482.

4. L. Carter, F. Bélanger, The utilization of e-government services: citizen trust, innovation and acceptance factors. Information Systems Journal, 15(1), 2005, pp. 5-26.

5. M. Crouch, H. McKenzie, The logic of small samples in interview-based qualitative research, Social Science Information, 45(4), 2006, pp. 483-499.

6. W. L. Currie, Contextualising the IT Artefact: Towards a wider research agenda for IS using institutional theory, Information, technology and people, 22(1), 2009, pp. 63-77

7. W. L. Currie, M. W. Guah, Conflicting institutional logics: a national programme for IT in the organisational field of healthcare, Journal of Information Technology, 22(3), 2007, pp. 235-247.

8. R. M. Davison, C. Wagner, L.C. Ma, From government to e-government: a transition model. Information Technology and People, 18(3), 2005, pp. 280-299.

9. T. Diefenbach, New Public Management in Public Sector Organisations: The Dark Side of Managerialistic 'Enlightment', Public Administration 87(4), 2009, pp. 892-909

10. N. F. Doherty, M. King, From technical to socio-technical change: tackling the human and organizational aspects of systems development projects, European Journal of Information Systems, 14, 2005, pp. 1-5.

11. J. R. Gil-Garcìa, T. A. Pardo, E-government success factors: Mapping practical tools to theoretical foundations. Government Information Quarterly, 22(2), 2005, pp. 187-216.

12. B. Gupta, S. Dasgupta, A. Gupta, Adoption of ICT in a government organization in a developing country: An empirical study, Journal of Strategic Information Systems, 17(2), 2008, pp. 140-154. 
13. Z. Irani, P. E. D. Love, S. Jones, Learning lessons from evaluating eGovernment: Reflective case experiences that support transformational government, Journal of strategic information systems, 17 (2), 2008, pp. 155-164

14. Z. Irani, M. Themistocleous, P. E. D. Love, The impact of enterprise application integration on information system lifecycles, Information \& Management, 41(2), 2003, pp. 177-187.

15. P. T. Jaeger, K. M. Thompson, E-government around the world: lessons, challenges, and future directions. Government Information Quarterly, 20(4), 2003, pp. 389-394.

16. M. Janssen, A. M. Cresswell, An enterprise application integration methodology for egovernment, Journal of Enterprise Information Management, 18(5), 2005, pp. 531-547.

17. K. N. Jun, C. Weare, Institutional Motivations in the Adoption of Innovations: The Case of EGovernment, Journal of Public Administration Research and Theory, 21 (3), 2011, pp. 495-519

18. W. Ke, K. K. Wei, Successful e-government in Singapore, Communications of the ACM, 47(1), 2004, pp. 95-99.

19. S. Kim, H. J. Kim, H. Lee, An institutional analysis of an e-government system for anticorruption: The case of OPEN, Government Information Quarterly, 26(1), 2009, pp. 42-50.

20. C. Koh, V. Prybutok, X. Zhang, Measuring e-government readiness, Information \& Management, 45 (8), 2008, pp. 540-546.

21. T. Kostova, K. Roth, M. T. Dacin, Institutional Theory in the Study of Multinational Corporations: A Critique and new directions. Academy of Management Review, 33(4), 2008, pp. 994-1006.

22. R. Lamb, R. Kling, Reconceptualising Users as Social Actors in Information Systems Research, MIS Quarterly, 27(2), 2003, pp. 197-236

23. H. Liang, N. Saraf, Q. Hu, Y. Xue, Assimilation of enterprise systems: The effect of institutional pressures and the mediating role of top management. Management Information Systems Quarterly, 31(1), 2007, pp. 59-87.

24. V. Prybutok, X. Zhang, S. D. Ryan, Evaluating leadership, IT quality, and net benefits in an egovernment environment, Information \& Management, 45(3), 2008, pp. 143-152.

25. H. Teo, K. Wei, I. Benbasat, Predicting intention to adopt interorganisational linkages: An institutional perspective, MIS Quarterly, 27(1), 2003, pp. 19-49.

26. UN, E-Government Survey 2012: E-Government for People, Department Economic and Social Affairs, United Nations, New York, 2012.

27. V. Weerakkody, M. Janssen, Y. Dwivedi, Transformational Change and Business Process Reengineering: Lessons from the British and Dutch Public Sector, Government Information Quarterly, 28(3), 2011, pp. 320-328. 